\title{
Punk History: Resisting Gender Norms of Femininity
}

\author{
Mildred Van Bergen \\ SUNY Empire State College Old Westbury, USA
}

\begin{abstract}
Adolescent girls often experience a decline in their self-esteem as they begin to realize their second-class cultural status on the road to adulthood. Studies have demonstrated that exposing girls to creative outlets and/or experiences can have a positive impact on how they see themselves as valued human beings. In this article, I explore how creative energy and its power often connect to a male point of view and experience. The do-it-yourself attitude of the early days of punk rock presented an opportunity for women to not only find their own voice and make their own music, but to question the prevailing gender roles of the times. Examining the work of Patti Smith, and her strong desire to be creative in different areas while challenging gender roles in the process, I also explore how Smith influenced other young women who would emulate her strong example, focusing on The Slits, a punk rock band formed by adolescent girls. The lack of information about this unique group of girls speaks to the lack of importance placed on female artists in general; in some ways, this connects to the lack of self-confidence some girls can endure during puberty. Through the lenses of several disciplines, this article investigates how certain perspectives of the punk rock era encouraged young women's creativity and self-esteem, ultimately changing the way they viewed themselves as well as how they were viewed by the world.
\end{abstract}

Keywords: gender, punk, creativity, feminist

As girls approach their adolescent years, their life worlds begin to change, both inside and out. Numerous studies have explored the extreme loss of self-confidence suffered by many girls as they enter and endure puberty and their teenage years on the way to being young adults (Wellesley College \& American Association of University Women, 1992; Brown \& Gilligan, 1992; Pipher, 1994; Orenstein, 1994). However, others have challenged this outcome. Former philosophy professor Christina Hoff Sommers (2001) argued that feminist researchers, in particular Carol Gilligan, Mary Pipher, David and Myra Sadker, and researchers representing the American Association of University Women, have "manufactured" a crisis concerning girls (p. 124). While Sommers's claim is focused on the soundness of research methodologies chosen, the abundance of relevant research to date suggests that for girls, the middle grades can be a time of significant decline in self-esteem and academic achievement.

Takayoshi (1999) recognized the loss of self-confidence that girls feel at this age and the subsequent need to further research this population in order to help them regain their self-esteem. Researchers Schilt (2003) and Cassidy (1999) argued many girls do not suffer low self-esteem, or lack of drive, and these specific groups of girls should be the focus of further academic research. Their findings suggested that the self-expression practiced

Mildred Van Bergen, Ph.D., Director of Academimc Support, SUNY Empire State College Old Westbury USA. 
by adolescent girls plays a vital role in fostering their self-esteem. Each of these scholars have acknowledged the importance of connecting adolescent girls to creative outlets, either those they find themselves or are introduced to by others, such as women- or girl-centered creative workshops, media literacy classes in school, extra-curricular or community-based forums that encourage creativity and critical thinking.

Taking the research mentioned above as a point of departure, I examine how the creative process, the creation of art more generally, can empower young women to self-actualize and own their femininity (or redefine it) in order to realize their full potential. Focusing on a particular period of time, a specific art form, and its connection to protests, I explore how women and/or young girls in the early days of punk rock in America and England used the music and its surrounding culture to become the subjects of their own lives, protests, and creative expression. In addition, I analyze the avenues of self-expression that punk rock offered women and girls at the time and how this set of cultural conditions helped them to confront and challenge stagnant female gender rolesby considering such questions as: How did the art form of punk rock help women to protest against unfair and unequal gender norms at the time? How did this kind of performance art help those exposed to it to critically examine gender roles in general? What was the societal impact of girls protesting in this manner? In what ways did girls use punk rock to connect performance with protest? What were the circumstances that led to this opportunity for girls to be involved in what was once considered a male culture? Employing an interdisciplinary approach, including disciplines such associology, psychology, art, and art history, I analyze how the punk rock scene of the late 1970's and early 1980's in America and England may have affected the girls who engaged with it as well as the surrounding culture at the time.

Focusing on two female-driven punk rock acts, Patti Smith, and the all-girl band The Slits, this article will analyze how each developed and used its artistic and creative abilities to protest and challenge the female gender normsof the time. This analysis primarily explores two texts: Just Kids (2010), the autobiography/memoir of Patti Smith, and Zoe Street Howe's (2009) Typical Girls? The Story of The Slits.

Women's contributions to music have along but largely unwritten or forgotten history. The women who experienced the freeing aspects of punk rock did so on the shoulders of other women performers who came before them; the creative process and its connection to the power of performing, were critical to both populations, despite their sometimes limited creative control and attendant power. Historically, creativity, and its value have been understood in terms of how men engage with it (Eisler \& Montuori, 2007). Since its conception as a field of study, the connection between creativity, its empowering effects, and the role of females has been understood in terms of reproduction. According to feminist writer and creator Adrienne Rich, this kind of thinking stems from an ancient envy, awe, and dread that men have for a woman's capacity to create life; it takes the form of hatred for every other female aspect of creativity (Nicholson, 1997, p. 377). Rich's point is demonstrated in the statement made by Hans Hoffman, an abstract artist of the 20th century regarding the work of his pupil, Lee Krasner: "This is so good, you would not know it was painted by a woman” (Fisher-Sterling, 1995 p. 193). Hoffman did not think to disguise his opinion in a more tactful manner. The transparent ignorance of Hoffman's remark illustrates an attitude about women's endeavors in the arts that still prevails. In The War Against Women (1992), feminist philosopher and theorist Marilyn French concurs with Rich's opinion regarding the negative response to women artists, claiming that women who attempt to challenge or question artistic depictions of themselves are considered dangerous: 
And what we cannot fail to see in art is men's hatred of women-and acannibalistic male psyche. Women who analyze or depict this male psyche areusually accused of "male bashing." A society complacent about negative imagery in the arts grows absurdly censorious when women attack male values, behavior, and images. (French, 1992, p. 164)

Rich refers precisely to women's creative analysis and depiction of oppressive male cultures. The female artists, whose creative works, biographies, and autobiographical accounts are analyzed here, combat the anger often aimed at female creativity by artistically questioning it.

On the subject of women in punk rock, many writers andcritics agree that their artistic contributions are connected to the past and the present, yet they are always evolving (Becker, 2012; Kennedy, 2012; Kane, 2012). They do however have differing opinions when it comes to Patti Smith and her value to women in the punk rock scene, specifically regarding her originality and staying power. In “The World's a Mess. It’s in My Kiss: Punk Women and Why They Matter”, Becker (2012) maintained that Patti Smith is overly celebrated for her contributions to punk, while other women punk musicians are not given such respect and are often reduced to being connected to particular fashions or male band members. Interestingly, Smith is barely mentioned in LeBlanc's (2005) Pretty in Punk, which is one of the more recognized scholarly texts on the subject of women in punk rock. Becker's bias may have something to do with her own personal connection to the punk scene. Speaking in reference to theall-male bands she obsessed over, Becker (2012) states that she "deeply wished one would materialize in my living room and ask me to be their girlfriend” (p. 119). Becker seems to describe herteenage self as the kind of person that Smith would never be. Not surprisingly, Becker states that although she was aware of Smith's work and influence, she did not connect to her androgynous look and extreme artistic material.

Musician Thurston Moore opposes Becker's claim that Smith is unduly celebrated as being significant to the early punk rock era, while other women are not, claiming that her unique creative processes and presentations justify her unrivalled status, claiming:

Patti Smith is really interesting to me. She's one person who really predates punk, as far as being an artist, a writer and a performer. But at the same time she really informed punk to such a degree, she's very significant in where she comes in. (Letts, 2005)

Moore's comments are echoed in the writings of Daniel Kane, who claims that Smith's influence and staying power are related to her self-presentation as a poet with a privileged view. He believes that she teaches audiences to equate poetry with rock star potential. In her autobiography she states that in her initial public poetry reading, her desire was clear:

My goal was not simply to do well, or hold my own. It was to make a mark at St. Mark’s. I did it for poetry. I did it for Rimbaud, and I did it for Gregory. I wanted to infuse the written word with the immediate and frontal attack of rock and roll. (Smith, 2010, p. 180)

Smith was clearly not looking to fit in within the established genre, but rather create a powerful new one.

Author Deborah Kennedy believes that one of the reasons for Smith's strong influence and staying power is her ability to be interdisciplinary in her creative areas which include poetry, visual art, music, and performance. Kennedy sees Smith's eventual identifiable androgynous performance appearance as more of a signature trademark than a gender statement (similar to that of David Bowie). She quotes Smith as saying she is "more 
concerned with the work people do, than with their gender” (Kennedy, 2012, p. 238). Other writers on the topic support Smith's claim about herself.

Kane (2006) takes Kennedy's views one step further, suggesting that not only was Smith synthesizing different modes of creativity, but she was also strategically presenting her art with a challenging and heroic aim. Smith herself states that "my urge to express myself was my strongest desire” (Smith, 2010, p. 6). From an early age, Smith clearly connected creativity with power. Punk rock was a forum where young girls could learn to nurture their self-esteem through their own self-expressions.

During the mid to late 1970s, another female-fueled punk rock act emerged that was influenced by the work of Patti Smith. In fact, the founding members of The Slits met up at a Patti Smith concert. The two young women, 14-year-old Ari Up and 21-year-old Paloma Romero (aka Palmolive) connected to the physical presence of Smith, her uninhibited performance, and the complete omission of what was considered to be "sexy". Future The Slits member Viv Alber tanreflects on Smith's influence on her as she was learning to play guitar and perform. Before Smith, Viv looked to the Sex Pistols as role models. She saw in Smith a new way to connect power with sexy:

That was a massive moment Horses coming out...couldn't wait for it to come out...when I got home and put it on, my God, this was likethe first woman in my life who had the same feelings about anything in the world that Ihad. Thank God I heard it, and to hear the passion of her and the sexiness of her without being all tits and arse. (Howe, 2009, Chapter 1)

Clearly Smith had a huge impact on the girls who would become The Slits. Smith's influence fueled the desire of these young girls to act on their need to be heard via artistic expression. The Slits were born, demonstrating how women in punk rock have connected to the past in order to create their present. Smith's physical and emotional attitude on stage was uncommon for women performers at that time (at least the ones who were recorded or remembered in some way) (Howe, 2009). While Smith had an effective, powerful, and unique approach to changing viewpoints of traditional gender roles, The Slits used different methods, through the art form of punk rock to expose and protest against unfair and unequal gender norms at the time. Smith saw herself as a performer in the sense that she performed to an audience rather than with, or even for, an audience. The Slits were more indebted to a feminist ideology, leveling the playing field of the spectator and the performer (Kane, 2012, p. 119). Smith understood the two to be unequal and hierarchical, as she describes her experience in both roles:

There's excitement on the both sides you know. And being a spectator you can never have the powerful feeling you feel on stage you know... you know so that's...

I'm going though that right now. Well, everybody has to go through it when you go from one to the other. You have to transcend the, the, the, excitement of waiting for the curtain to open in when you're in front of the curtain, tolike, the surge of power you feel when people are applauding for ya. Man—what a feeling-I have to admit it's a...even better than being with a man. It's almost better than that. (Astralasia 23, 2007)

The girls who met while admiring Smith were unwilling to remain just fans, but they did not see themselves as "privileged viewers" in the same way that Smith saw herself. However, The Slits were formed that night, with rehearsals beginning the next day.

Writers and critics on the subject of women in punk, including The Slits, have different opinions on their impactand how punk rock supported their efforts. But many writers agree that The Slits, the band's effect on 
women in music, and on culture at large, has received little critical attention. For example, while researching the topic of "women in punk”, I found that LeBlanc's (2005) Pretty in Punk is referenced quite often. In her 286-page text, Le Blanc dedicates just four sentences to The Slits when discussing how women in punk resisted gender differences. Zoe Street Howe mentions in the introduction of her book that she began researching and writing about The Slits primarily because no such work existed. Band member Tess Pollitt is also quoted in Howe's introduction; she theorized that the band may have "been written out of the history books, or the her-story books" (Howe, 2009, Introduction) because the band was hard to handle and belonged to no single category. The female sexual connotation to the band's name (The Slits) exposes "the mutual dependence of the concepts of normalityand abnormality in sexual matters" expressing "hostility toward the obsession with the subject matter shared by puritans and pornographers” (Kane, 2012, p. 27). Although the all-male group The Sex Pistols named their band in a similar vein, they garnered far more recognition and press attention than the Slits. I believe that both bands chose their names intentionally in order to raise and question culturally embedded ideas about sex and sexuality. In the case of The Slits, they wanted to go beyond sexual taboo in order to address the sexual gender roles and their oppressive effects on women. Their spot on-target may have been too eye-opening for even those who wanted to support them in the punk scene, so that knowledge of their existence was only considered valuable by those few "in the know".

Brian Cogan points out a gaping hole in the literature when it comes to discussing gender issues or the acceptance of women as full participants in the initial punk scene. He also argues that while The Slits was not one of the best known original British punk bands, they were among the most important (Cogan, 2012, p. 122), because much like Patti Smith, they were artistic and creative in their exploration of gender and sexuality using the platform of punk rock without adhering to any specific manifesto. Both acts used an "anything goes" attitude of possibility (albeit limited by what has been made available to women) to develop their style through reinventions, to instill long-lasting and far-reaching effects, and to change the perception of rebellion and protest. Patti Smith and the young girls who were The Slits were among the group of females who appeared full of self-esteem and drive (which researchers Schilt and Cassidy argue are persistently overlooked). Although they were part of the early punk rock era, they outgrew its limiting labels in order to question the value of definitions. Their approaches to achieving this goal were similar yet different. They both used, to differing degrees, the performingof "ugliness", defined by writer Eilerass (1997) as "an intentional deviation from nice gentle pretty ways of looking talking, behaving, and visualizing” (p. 122) as a form of resistance and as catalyst for progressive discussions on female creativity.

Schilt (2003) argued that being exposed to creative works or creative outlets can help girls to value their adolescent voices instead of losing them. As adolescent themselves, the members of The Slits as well as Patti Smith were all exposed to or involved in creative projects that inspired them. Much like the founding members of The Slits, Patti Smith was influenced by the artists she was exposed to as a young girl. Smith recalls more than fondly, but rather with a life changing affirmation, how her parents struggled to take her and her three siblings on a bus to the Museum of Art in Philadelphia. She has the same kind of epiphany during her first visit to the museum that Viv Albertine experienced upon hearing Patti Smith for the first time:

...I came face to face with art. I felt a physical sense of physical identification with the long, languorous Modiglianis; was moved by the elegantly still subjects of Sargent Thomas Eakins; dazzled by the light that emanated from the 
Impressionists. But itwas the work in a hall devoted to Picasso, from his harlequins to Cubism that pierced the most. His brutal confidence took my breath away...I'm certain as we filed down the great staircase, that I appeared the same as ever, a moping twelve year old, all arms and legs. But secretly, I knew I had been transformed, moved by the revelation that human beings create art, that to be an artist was to see what others could not. (Smith, 2010, p. 11)

Interestingly, all the artists Smith felt so inspired by were male. Yet she still connected to their unique individualism and was able to envision herself as one of them. She was able to see that within her "awkward" female pubescent body were possibilities that encompass being human. The "brutal confidence" that invaded the museum air was contagious and inspiring to Smith and helped her teenage self-begin to find and develop her own voice. While lead singer for The Slits, Ariane Forster, aka Ari Up, was also exposed to creativity at an early age, her experiences were more musically focused.

Ari Up was surrounded by musical influences since the day she was born. Her mother was a professional music promoter and would also let struggling musicians stay at their house, including people like Jimmy Hendrix, Barry Gibb, and Johnny Rotten of the Sex Pistols, who was Ari's favorite, and would soon be her inspirational stepfather. Ari’s mother Nora Shepard recalls how Johnny Rotten was an influence on her daughter:

I wasn't interested in John when we first met...I came to notice John because Ariane was a fan... Ariane jumped on stage at a Pistols concert in SoHo, kissed him and said "You'rethe greatest." John used to come around the house with...Sid and the others. It was so wild. Some of the girls started to cut up the curtains, the kitchen was black and burnt out, it looked horrible. We had some terrible scenes in there. (Howe, 2009, Chapter 2)

Like Smith, Ari's main artistic influences were male (although she was a huge fan of Smith). The fact that her music producer mother befriended so many of them allowed Ari an almost secret passage into their creative and chaotic worlds. Being immersed in these surroundings during her formative years may have given Up the same "brutal confidence" Smith felt, to embark on a creative rebellion.

Both Patti Smith and The Slits demonstrated what could be considered an "ugliness", described by Karina Eileraas as a form of resistance to the dominant cultural representation of women. This "ugliness” was portrayed through various methods, among some of the more popular sites being "album cover art. Image, voice, sound, language, lyrics, stage antics, sexuality, and the body” (Eileraas, 1997, p. 122). Smith’s ideas about challenging accepted gender behavior and adhering to culturally constructed views about feminine beauty began at an early age. As an 11-year-old girl, while playing and wrestling with her younger brother in the hot summer sun, Smith was both mystified and angered by her mother's request to "Put a shirt on! Hot or not, you're about to become a young lady” (Smith, 2010, p, 10). While putting her shirt on, feeling betrayed and unnatural, Smith describes how she connected her gender to a culture that controlled what it should look like and what it could do, and most importantly, that it was destined to stay that way.

I ruefully watched my mother performing her female tasks, noting her well-endowed female body. It all seemed against my nature. The heavy scent of perfume and the red slashes of lipstick, so strong in the fifties, revolted me. For a time I resented her. She was the messenger and also the message...I dreamed of travel. Of running away and joining the foreign legion, climbing the ranks and trekking the desert with my men. (Smith, 2010 p. 10)

In this memory/example Smith begins to understand the attractiveness of being ugly, that is if being ugly meant being who she was. She claimed at that moment she would not become anyone but herself—a young lady who would not suffer what she saw as the monotonous yet expected routines, accompanied by specific 
controlling and signifying messages of static ideas about being female that surrounded her. Musician Tanya Donelly of the band Belly echoes Smith's early revelations about connecting ugliness with power as a young girl:

I watched a lot of teenage girls my age get distracted-boys would become their mirrors, whereas our guitars were our mirrors...the fact that we were ugly was a real blessing! I don't think you ever lose that feeling of ugliness, once you've had it. (Eileraas, 1997, p. 127)

Both Evans and Smith experienced ugly power with a sense of freedom to define ideals such as ugly or pretty in their own terms. Smith used her appearance and voice to exhibit these features.

In her autobiography Just Kids, Smith claimed that some people took her message and interests in the wrong way, stating, "They figured I was a latent homosexual, or maybe just acting like one, but I was merely a Mickey Spillane type, exercising my hard, ironic edge” (Smith, 2010, p. 201). Other artists interpreted that ironic edge to be quite unique and powerful. Performing in ratty jeans and tee shirts, Smith helped to make "ugly" very attractive. Alice Bag of The Bags connected with Patti’s ability to make being strong, loud, and powerful characteristics of being female; she stated in an interview for the film Punk: Attitude:

I'd seen a lot of women get up on stage and look pretty and sing and have pleasing qualities to their voices and do the whole vamp thing, but Patti was kind of scrawny. She didn't really try to look glamorous. She had more power than any of those women. She had more to say. She was more exciting. She was...she had the kind of power that the men had. (Letts, 2005)

Bag's description of watching Smith, through the lens of a spectator, an audience member, demonstrates how Smith strategically utilized her self-described hard ironic edge together with her artistic musical endeavors to successfully connect the idea of femininity with power. Clearly she had "more to say" than the typical female performers at the time, who according to Clawson (1999) were isolated to being singers or dancers on stage, with no clear opportunity to create and perform their own art. Clawson posits:

...ensemble instrument playing is the musical activity from which women have been most fully excluded, in contrast to singing, where women have achieved significant recognition in both the classical and pop worlds. Such exclusion limits women’s access to the fullest range of musical creativity. (Clawson, 1999, p. 194)

This kind of exclusion echoes and supports the ideas of Rich (1995) and French (1992) in terms of devaluing and limiting women's exposure to creative expression. Even when the girl groups are noted in rock and roll history texts, "it has been to praise the innovations of their Svengali-like male producers, or songwriting teams that provided them with their hits" (Cateforis, 2012, p. 43).

When certain girl groups were popular in the 1960s, there was usually a man at the helm of creative control, directing the group, producing the group, advertising, managing, and even co-writing the songs. Phil Spector had much of the creative control of the groups that he worked with, such as The Ronnets and the Crystals. Ari Up describes why such groups demonstrated how women were limited in how they could express themselves while also examining the circumstances that made The Slits distinctive:

The idea of a girl band, I can understand was yucky because...that's exactly the problem that girls were always put together in a very fabricated sort of pretentious way where usually a man is behind it. Telling them every move what to do. And we're like the first band EVER, to build ourselves, to monitor ourselves, to create ourselves to make our own music, with our own artistic control. And the firstgirls to pick up our own instruments without any kind of input from anyone else. So that's what made The Slits unique. (Letts, 2005) 
In addition to playing their own instruments, they wrote their own songs, which were often about the absurdity connected to the cultural constructions defining how young women should live. Their most successful single "Typical Girls" epitomized the band and their message as it railed against a society that demanded that girls “Don’t create, Don’t rebel, Have Intuition, Don’t drive well” (Typical Girls Song). Up, an adolescent girl at the time Typical Girls was released, creatively addressed the difficulties that many girls are forced to wrestle with as they become adults by making fun of the tired clichés while, at the same time exposing the powerful and dangerous effects they still have on their desired market audience:

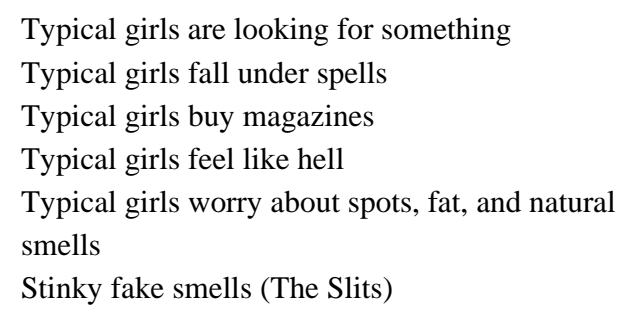

In the line "Typical Girls feel like hell”, Up reveals to among others, an ignorant audience, that as girls attempt to conform to the societal norms of their gender and age, they end up losing themselves in the process and "feeling like hell".

As Patti Smith and The Slits each demonstrated how women in the 1970's found ways to engage with punk rock as a means to express their views on femininity and power relationships at large using varying strategies, punk music and the punk "attitude" continues to support and empower women to recognize their agency and rights as human beings. Most recently, Pussy Riot, a Russian punk rock group made up of young Russian women, have used the punk platform to challenge Russian society through performance art. Their songs and antics expose the power of Russia's President Putin and the Russian Orthodox Church, targeting what they believe to be the anti-female, anti-gay, anti-human rights agendas connected to each power structure. Pussy Riot's performances include what they refer to as a "punk prayer" entitled "Holy Shit", with lyrics asking the Virgin Mary to throw Putin out of office. In February 2014, the group performed their song "Putin Will Teach You to Love the Motherland” under a sign advertising the Sochi Olympics to protest Russia’s lack of freedom of speech. This performance was being filmed, to be used in their new video, and ironically it includes the group being beaten and horsewhipped by Cossack militia. In April of 2014, Pussy Riot member Nadya Tolokonnikova addressed an audience in New York City at the Womenof the World Summit, saying in English,

While we were in prison, we learned to be inspired by little things, aray of sunshine through the bars, a strange shaped crack in the ceiling...Punk culture has taught us that to be moderate and restrained is not always the correct choice. When your intuition is telling you that the time has cometo leave behind your moderation, do it! (Zoladz, 2014)

The Punk platform provided and continues to provide ways for women to "learn to be inspired" by their own lives. Artists like Patti Smith, The Slits, and Pussy Riot have enlightened their audiences that rebellions and protests are not stagnant. They depended on creative outlets to reinvent themselves, and demonstrated how women and men can benefit from female perspectives and female abilities to creatively engage in changing how gender roles are understood. 


\section{References}

Astralasia 23. (April 14, 2007). Patti Smith-Horses [Video file]. Retrieved from https://www.youtube.com/watch?v=qKOULF922Rs

Becker, S. (2012). Editor's note: “The world's a mess. It’s in my kiss”: Punk women and why they matter. Women’s Studies, 41, 117-120.

Brown, L., \& Gilligan, C. (1992). Meeting at the crossroads: Women's psychology and girls' development. Cambridge: Harvard University Press.

Cassidy, C. (1999). Girls in America. New York: TV Press.

Cateforis, T. (Ed.). (2012). The rock history reader. London: Routledge.

Clawson, M. A. (1999). When women play the bass: Instrument specialization and gender interpretation in alternative rock music. Gender and Society, 13, 193-210.

Cogan, B. (2012). Typical girls?: Fuck off, you wanker! Re-evaluating The Slits and gender relations in early British punk and post punk. Women's Studies, 41, 121-135.

Eileraas, K. (1997). Witches, bitches \& fluids: Girl bands performing ugliness as resistance. TDR, 41(3), 122-139.

Eisler, R., \& Montuori, A. (2007). Creativity, society, and the hidden subtext of gender: Toward a new contextualized approach. World Futures: Journal of General Evolution, 63(7), 479-499.

Fisher-Sterling, S. (1995). Women artists: The national museum of women in the arts. New York: Alberville Press.

French, M. (1992). The war against women. New York: Summit Books.

Howe, Z. S. (2009). Typical girls? The story of The Slits [Kindle version]. London: Omnibus Press.

Kane, D. (2012). "Nor did I socialize with their people”: Patti Smith, rock heroics and the poetics of sociability. Popular Music, 31(1), 105-123.

Kennedy, D. (2012). Afterword: From Patti Smith to Paramore. Women’s Studies, 41, 238-244.

LeBlanc, L. (2005). Pretty in punk: Girls'gender resistance in a boys'subculture. New Brunswick, NJ: Rutgers University Press.

Letts, D. (Director). (2005). Punk: Attitude [Documentary]. Metropolis Productions.

Nicolson, P. (1997). Motherhood and women’s lives. In V. Robinson and D. Richardson (Eds.), Introducing women's studies (pp. 375-399). London: Palgrave.

Orenstein, P. (1994). Schoolgirls: Young women, self-esteem and the confidence gap. New York: Dell.

Pipher, M. (1994). Reviving Ophelia. New York: Ballantine Books.

Rich, A. (1995). Of woman born. New York: Norton.

Schilt, K. (2003). "I'll resist with every inch and every breath”: Girls and Zine making as a form of resistance. Youth \& Society, 35(1), 71-97.

Smith, P. (2010). Just kids. New York: Harper Collins.

Sommers, C. H. (2001). The war against boys: How misguided feminism is harming our young men. New York: Simon \& Schuster.

Takayoshi, P. (1999). No boys allowed: The world wide web as a clubhouse for girls. Computers and Composition, 16, 89-106.

The Slits. (1979). Typical girls. On Cut [CD]. Island.

Wellesley College \& American Association of University Women. (1992). How schools shortchange girls: The AAUW report: A study of major findings on girls and education. Washington, DC: AAUW Educational Foundation.

Zoladz, L. (April 10, 2014). Pussy Riot's Nadya Tolokonnikova and Masha Alyokhina. Pitchfork. Retrieved from https://pitchfork.com/features/interview/9374-nadya-tolokonnikova-and-masha-alyokhina-of-pussy-riot/ 